\title{
Race and Mystery in Cape Cod
}

\section{NICHOLAS POWERS}

Bill Fletcher Jr., The Man Who Fell from the Sky (Brooklyn: Hard Ball Press, 2018), 350 pages, \$15, paperback.

It begins with an assassination. In Bill Fletcher Jr.'s first novel, The Man Who Fell from the Sky, the sleepy Cape Cod town of Osterville has blood on its hands. In this murder mystery, Fletcher digs through layers of racism in Southern Massachusetts to uncover more than the killer's identity. The novel compellingly exposes the racism of society, turning its victims against each other.

When Margie Smith finds her husband TJ (short for Thomas Julius) shot dead in his car, Detective Vincent Amato and, later, reporter David Gomes try to solve the murder in a town riven with racial tension. Going from door to door, they piece the puzzle together, untangling a knot of relationships going back to the Second World War. TJ's murder is interwoven with the larger conflict between the town's Cape Verdean immigrant community and its African-American community over what "black is."

The subtheme of the fluidity of blackness runs through the novel. In one telling scene, Gomes is at a party where his Uncle Marcelino (who is described as being dark skinned) yells, "Listen, we're Portuguese. Yeah, our family is from Cape Verde, but we're Portuguese. I'm sick of you calling me 'black.' Our ancestors were never slaves!” Later, Gomes speaks with a white detective who, in an expression of nonchalant racism, remarks that he expected "someone Spanish." Gomes explains that his last name ends in an $s$ and not a $z$.

Two conflicts drive The Man Who Fell from the Sky. The first is the explicit murder mystery. But boiling beneath is a mediation on race. In many ways, the book uses the former to explore the latter, smartly avoiding cliché backdrops like New York or London and instead situating the story in a small, mostly white town that serves as an odd crossroads for the black Atlantic. Both conflicts collide in the finale as Gomes is marched into an empty building with a .45 caliber gun aimed at his back.

The Man Who Fell from the Sky is a fast, fun read. And it stands in the tradition of black authors, like Walter Mosley and Chester Himes, who

Nicholas Powers is a professor, poet, and journalist. He is the author of The Ground Below Zero: 9/11 to Burning Man, New Orleans to Darfur, Haiti to Occupy Wall Street (Upset Press, 2015). 
have used fiction to investigate race and class, diaspora identity and crime. The book is also a promissory note.

Fletcher is a professional writer, activist, and scholar. Reading the crisp prose, one gets pulled into the dream state of a good story. You forget that you're turning pages and are lost in the world he created. It is a satisfying first novel - so much so that I am left wanting another book. But not another murder mystery. No, instead, I want to see what happens when Fletcher moves beyond the guardrails of genre to expose the complexities of life that flash between the plot devices.

Statement of Ownership, Management and Circulation (Required by 39 U.S.C. 3685)

1. Title of publication: MONTHLY REVIEW organization, its name and address must free): 176. e. Free distribution outside the 2. Publication 0036-1520. 3. Date of fil- be stated). Name: Monthly Review Foun- mail (carriers or other means): None. f. Total ing: September 10, 2019. 4. Frequency of dation, 134 W. 29TH Street, Suite 706, New free distribution: 176. g. Total distribution: issues: Monthly (except July/August when York, NY 10001. 11. Known Bondholders, 3,870. h. Copies not distributed: 547. i. combined). 5. Number of issues published mortgagees, and other security holders Total: 4,417. Percent paid and/or requestannually; eleven. 6. Annual subscription owning or holding one percent or more of ed circulation: $95 \%$. Actual no. of copies rate: \$39. Complete mailing address of total amount of bonds, mortgages, or oth- of single issue published nearest to filing known office of publication: 134 W. 29TH er securities: None. 12. For completion by date: a. Total no. copies (net press run): Street, Suite 706, New York, NY 10001. nonprofit organizations authorized to mail 4,420. b. Paid and/or requested circulation 8. Complete mailing address of known at special rates: The purpose, function, and (1) Paid or requested mail subscriptions office of publication: Monthly Review, nonprofit status for federal income tax pur- (include advertisers' proof/exchange cop134 W. 29TH Street, Suite 706, New York, poses has not changed during the preced- ies): 3,414. (2) Sales through dealers and NY 10001. 9. Full names and complete ing twelve months. 13. Publication name: carriers, street vendors, and counter sales addresses of publisher, editor, and man- Monthly Review. 14. Issue date for circu- not mailed: 209. (2) c. Total paid and/or reaging editor: Publisher: Monthly Review lation data below: September 2019. 15. quested circulation: 3,623. d. Free distribuFoundation, 134 W.29TH Street, Suite 706, Extent and nature of circulation: Average tion by mail (samples, complimentary, and New York, NY 10001. Editor: John Bellamy number of copies each issue during pre- other free): 114. e. Free distribution outside Foster, 134 W. 29TH Street, Suite 706, New ceding twelve months; a. Total number of the mail (carriers or other means): None. f. York, NY 10001. 10. Owner: (if owned by copies (net press run): 4,417. b. Paid and/ Total free distribution: 114. g. Total distribua corporation, its name and address must or requested circulation (1) Sales through tion: 3,737. h. Copies not distributed: 683. be stated and also immediately thereafter dealers and carriers, street vendors, and i. Total: 4,420. Percent paid and/or requestthe names and addresses of stockholders counter sales (not mailed): 215 (2) Paid ed circulation: 97\%. 16. This Statement of owning or holding one percent or more or requested mail subscriptions (including Ownership will be printed in November of the total amount of stock. If not owned advertisers' proof copies/exchanged cop- 2019 issue of this publication. 17. I certify by a corporation, the names and addresses ies): 3,479 . c. Total paid and/or requested that all information furnished on this form of the individual owners must be given. If circulation: 3,694. d. Free distribution by is true and complete: Gordon Beeferman, the publication is published by a nonprofit mail (Samples, complementary, and other Circulation Manager. Date: 9-10-2019. 